\title{
Developing Assertive Ability of Young Children as a Countermeasure Effort for Bullying Behaviour
}

\author{
Ernawulan Syaodih ${ }^{\mathrm{a}}$, Hany Handayani ${ }^{\mathrm{b}}$ \\ aUniversitas Pendidikan Indonesia, Bandung, Indonesia \\ ${ }^{b}$ Sekolah Tinggi Keguruan dan Ilmu Pendidikan Purwakarta, Purwakarta, Indonesia \\ Corresponding e-mail: ernawulansy@yahoo.co.id
}

\begin{abstract}
This paper which named Developing Assertive Ability of Young Children as A Countermeasure Effort for Bullying Behaviour is a study of literature reviews. This literature review means to explain the importance of assertive ability in early childhood as an effort to prevent bullying. Bullying is one kind of behaviour that frequently experienced by children. This behaviour often makes children feel pressured and disturbed, even may lead to harmful behaviour. Bullying is typically practiced by older kids to kids that seem to be weaker. This bullying behaviour may hamper the development and affect the further development of the child. One way that can decrease the chance of bullying victims in early childhood is by growing and improving assertive ability since early childhood. Assertive ability is an ability to show rejection and resistance by communicating what the child feel as bullying victim. Several ways that can be done in schools and homes are developing assertive abilities such as habituation, role modelling, and role playing.
\end{abstract}

Keywords: assertive ability, young children, bullying behaviour

\section{INTRODUCTION}

Bullying is one of violent behaviour done to people, particularly kids (both boys and girls). Riauskina, Djuwita \& Soesetio (2005) also explains that bullying is an aggressive behavior that happens numerous times by a child or a group of child that have greater power than the weaker ones. This bullying behavior is usually causing traumatic experience to victims. Next, Chesney-Lind \& Meda (2004) explains that bullying behavior happens to child or group of Childs with or without intention mock or insult their friends. Rigby (2002) says it in the paper that bullying behaviour is a desire that people have to do harmful and atrocious actions to other people. These kind of actions are including mocking, damaging things, physically hurting and intimidating other people.

Black \& Jackson (2007) mention that bullying is an proactive aggressive behaviour that contains deliberate actions in order to make oneself becomes powerful, hurting, and other people withdrew from $\mathrm{him} /$ her especially people with disabilities in physical, cognitive ability, capabilities, age, and even social status. This behaviour tends to be done repetitively. This leads to creation of habit for bullying perpetrators and will impact negatively to children as victims. Murphy (2009) explains that someone who used to be bullying victim usually have physical disabilities, economical limitation, weak features, or younger age. This behaviour tends to be done to get advantages or satisfaction for those who become penetrators.

Bullying which has not been prevented since early childhood might affect children in its teenage to be more violent and later to be antisocial. Therefore, there is much negative damage done to children as victims such as losing confidence, self inflicting shame, mental illness problems to minds, physical, and even possibilities to do suicide as an effect of desperation in the future. Based on data from Komisi Perlindungan Anak Indonesia (KPAI), there is a significant increase of bullying cases in children in Indonesia. In 2014, there are 461 violence cases to children in academical world, these increase to 478 cases in 2015 starts from sexual 
harassment, violence and mockery. Many of bullying victims end up having suicide (Source: Tribun Lampung, January 24th, 2016).

Realizing this issue, the first action that we could take as an educator and parent is to grow assertive behaviour since early childhood. Assertive behaviour is an ability where someone has a sheer confidence to state their arguments openly and confidently against matters that violate rules and norm, and also ability to say no to something that does not benefit them. French (1998) explains that a person's ability to express his/ her thoughts, without violating basic human rights, can be called as assertive ability. In other words, assertive ability is an ability of a person to show his/ her self principles.

Growing assertive ability to children can be developed through many aspects of learning in the kindergarten. The educator's job is not only educate the child but also planting values, and providing examples. Benyamin (2004) explains that children have rights to access education from parents, to ask questions which they do not understand, to obtain guidance, and to obtain love from their parents.

Children who have assertive ability will have skill to respect themselves and other people, and have better ability to socialize well. Willis \& Daisley (1995) explained that someone with assertive ability would show great respect to themselves and other people. Moreover, assertive child has other key behaviour such as honest, polite, respectful, calm, and able to socialize well so that they can provide a warm feeling around them.

This paper meant to be literature review tool to discuss what is bullying and to be assertive, forms of bullying, and factors that affect bullying behaviour. In general, this paper is an explanation on how important growing assertive ability in early childhood as a prevention for bullying.

\section{BULLYING BEHAVIOUR}

\subsection{Description of Bullying}

Bullying? This word is not a foreign word anymore in our ears, almost everyday media, be it online or offline provide news about the problems of bullying. Many cases of bullying in Indonesia is becoming a trend, there are so many bullying case happened from kindergarten until university. Since there are many cases happen, parents grow fear for their children that might become the next victim.

According to survey that is done by The Annual Bullying in Great Britain (which includes United
Kingdom, Scotland, Wales, and Ireland) in 2015, there are at least $50 \%$ people who have been bullied for minimum once in a week. Furthermore, $69 \%$ of children has witnessed other people being oppressed. While $43 \%$ of young generation has experienced intimidation.

What is bullying? Echols \& Hassan (1995) explains bullying comes from the word 'bully'. Tattum (1993) explains that bullying is an intentional desire to hurt and pressure someone else. It can be summarized that bullying is a behaviour that can threaten someone because it is categorized into violence. As mentioned by Elliot (2005), bullying is a behaviour that is intentionally done that makes the victim afraid or being pressured. Coloroso (2007) explained that the behaviour of making enemies and fighting that is done intentionally with aim to hurt other people is bullying. The same explanation stated by Rigby (2002) that bullying is an act of pressure done repeatedly, physically or psychologically to a weaker person.

\subsection{Forms of Bullying}

Bullying typically done repeatedly to the victim. In the last few years, we can find many cases of bullying in our environments. Riauskina (2005) \& Coloroso (2007) mentioned that bullying might consist in the following forms:

\subsubsection{Direct Physical Bullying}

This form of bullying involves physical contact with the victim, such as punching, pushing, biting, pulling hair, pinching, and all other forms of action that may cause physical harm to the victim.

\subsubsection{Direct Verbal Contact (Emotional Bullying)}

Direct contact verbal bullying consist of threatening, shaming, verbal abusing, naming with sarcastic elements.

\subsubsection{Direct Non-Verbal Bullying}

Non-verbal bullying consists of shaming with tongue, terrorizing and isolating.

\subsubsection{Indirect Non-Verbal Bullying}

This kind of bullying consist of neglecting, shaming the victim. 


\subsubsection{Sexual Bullying}

Sexual bullying consist of exhibitionism, abuse, or sexual assault to the victim.

Various forms of bullying can hamper the life of the bullied victim. Thus, parents, family and educators should act swiftly so that these cases can be minimalized and stopped, because it can be clearly stated that bullying will only result in negative impact.

\subsection{Factors Affecting the Bullying Behaviour}

Bullying behaviour does not happen arbitrarily. There are many cases that may cause person perform bullying or become bullying victim. Quiroz (2006) explains that there are many factors that may cause the bullying behaviour, as follows:

\subsubsection{Family}

Family is the main environment for kids to learn, most of the children's time will be spent with the family. Kids have an ability to imitate what they see, hear and feel around them. Parents or adults that exists around the kids are the decisive factor of their growth. Olweus (1993) stated that when kids are given excessive amount of punishment, it will increase the desire to hurt other people, making them a bully themselves. Consequently this will become a chain reaction where a bullied becomes a bully themselves.

Rigby (2002) in his research stated that when lack of communication between family members exist, it will affect the chance of kids become involved in bullying behaviour. Rigby also explained that most of bullying behaviour originated from less harmonious families. Bowers (1964) also described that when a father, the highest in the family hierarchy, punish the kids with a physical punishment, it will affect the kids to become a bully.

\subsubsection{Environment and Economy Condition}

In a condition that pushes someone to do anything, a low economical condition may trigger bullying behaviour in children for fulfilling their living needs, for example stealing in school, blackmailing, and also may accompanied by physical contact.

\subsubsection{Child Personality}

Children as a unique human possess different and various abilities. Each child's abilities to control anxiety and feeling to something, how child let go of an unrealistic competition, hatred that appears because of competition and inability to handle emotion positively will affect the occurrence of bullying behaviour (Quiroz, 2006). Bullying behaviour keeps happening repeatedly because the victims are reluctant to report their experience to teachers and parents. Most of the victims are scared of the bully, making the behaviour difficult to stop (Quiroz, 2006). Moreover, bullying in school happens because of arrogance of the bully themselves. This corresponds to statement by Colorosso (2007) that bullying behaviour is an actualization originated from the arrogance of a superior person.

\section{ASSERTIVE ABILITY}

\subsection{Definition of Assertive}

As stated in previous section, this bullying phenomenon is analogous to a tip of iceberg that hides big problem for parents and teachers. One of the way that can be done by parents and teachers is to grow the assertive ability since early childhood.

How important having this assertive ability in children? The answer is clearly very much important, because kids that has an assertive ability will be able to defend themselves and have a confidence to counter every form of bullying, as well as they can value other people better.

If a kid is able to convey a happy feeling, sad, angry, annoyed, and upset with honesty and openness according to what they feel without blaming anyone else, then the children can be called as having assertive ability.

Assertive ability is ability of a person to communicate honestly and openly about what he want, feel, and think to other people. Assertive ability is also ability to state needs, feelings, and thoughts as it is, defend personal rights as well as denying unthinkable requests (Rini, 2001, Rathus \& Nevid, 1983). Furthermore, Sunardi (2010) explains that assertive is an ability of a human to convey himself firm and open about thoughts, wishesm feels and emotions without negatively impact other people.

Willis \& Daisley (1995) described that assertive ability is an ability that shows value for himself and other people. Meanwhile Alberti \& 
Emmons (2002) mentions that assertive ability is an ability that makes someone able to act for the good sake of themselves, defend their rights without anxiety, express feelings comfortably and perform their rights without violating other people.

Based on the definitions presented, it can be summarized that assertive is an ability to communicate what is being felt, wanted, and thought to other people however with still keeping and valuing other people's thoughts.

\subsection{Assertive Ability Criteria}

Assertive ability that is developed since early childhood can be started with various forms of investment, such as investing in honesty, independence, and responsibility since early. Pratanti (2007) explained that someone that has an assertive ability is guided to be honest with himself and other people in expressing feeling, argument and needs firmly without harming anyone.

Pratanti also explains a number of criteria for someone to be called as having assertive ability, such as freedom to express feeling, thoughts and wishes, knowing their own rights, and ability to control anger. Palmer \& Froener (2002) mentioned some criteria of assertive is honesty, treating other people will respect, having a good relationship with other people, and also calm in their daily basis and showing a good sense of humor when facing tough situation.

Criteria of children having this assertive ability is shown in their ability to express thoughts and feelings to other people without harming anyone, and also the ability to request help to other people when in need, having a high curiosity and able to express their arguments honestly and openly.

\section{IMPORTANCE OF BEING ASSERTIVE IN EARLY CHILDHOOD AS AN EFFORT TO PREVENT BULLYING}

Being assertive since early childhood is very important in order to prevent oneself from bullying. Other benefit includes ability to prevent being taken advantage from other people based on one's weakness, high confidence, aggressiveness from other people, hurting other people, and ability to value oneself more and other people who are generally weaker.

Muhammad (2003) explains that being assertive have several advantages such as ability to understand and value other people more.
Bullying can be prevented by investing ability to be assertive since early childhood. Things that can be done at school include habituation or creating regular activities. Teachers can help at school by doing role-playing learning activities.

\subsection{Habituation}

One of activity that is done in Kindergarden is Habituation. Depdiknas Direktorat Pendas dan Menengah Direktoran TK dan SD (2007) stated that habituation activity is an activity that is done repeatedly and routinely to kids. Fadlillah \& Mualifatu (2013) stated that habituation has a deeper implication than implanting ways to behave and communicate, and also is more flexible, and can be done routinely, spontaneously, and programmatically. As such, Depdiknas Direktorat Pendas dan Menengan Direktorat TK dan SD (2007) explains that there are several habituation or regular activities at school:

1) Create a habit where children should face towards people who talk to them therefore children will learn to appreciate other.

2) Create a habit where children can express their opinion in an honest and open way to others.

3) Create a habit where children are always asked to apologise whenever they do a mistake. In return, children are also asked to say thank you if they get something or some kind of help from others.

4) Create a habit where children help each other with their friends.

5) Create a habit to always present themselves as clean and tidy at work, dressing up, and behave in daily life

6) Create a habit to always practice in order to be obedient and follow order of conduct to rules.

7) Create a habit to always be brave and have high curiosity.

8) Create a habit to always feel enough for achieving any accomplishment and desire to improve

9) Create a habit to always be responsible towards given task.

10) Create a habit to taking care of cleanliness of environment.

11) Create a habit to always control emotion.

12) Create a habit to defend themselves.

13) Create a habit to behave accordingly.

14) Create a habit to tolerate other people. 
15) Create a habit to make certain that learning activities become center attention to children.

16) Consequently, children will value each other.

\subsection{Role Modeling Activity}

Activity that can be done in order to build assertive ability since early childhood to prevent bullying can be done through giving direct wisdom or role modeling activity. Role modeling activity is something that can be done by giving reference or example to children on how to behave accordingly in direct. Teacher may also work as a model to student directly (Depdiknas Direktorat Pendas dan Menengah Direktorat TK dan SD 2007). Role modeling activity is aimed to direct children to various examples of role patterns acceptable by the society. Portraying the roles directly in the children's activities does this. in this case teachers act as the direct example for the children (Mayang, 2014). Depdiknas Direktorat Pendas dan menengah Direktorat TK dan SD (2007) explains several role modeling activity/ examples such as:

1) Try to talk in confidence.

2) Try to express opinion.

3) Dress tidy and politely.

4) Talk in good manner.

5) Never to eat while walking.

6) Put garbage to where it belongs.

7) Say greetings whenever meeting other people.

8) Present on time at school, etc

\subsection{Role Playing}

There are other things beside habituation and role modeling activity that can prevent bullying which is role playing activity. Role playing activity is something where children portray themselves as a role, thing, character, or any specific behavior by replaying certain activity. Children can learn to act as someone else therefore children will learn and understand character whom they played (Depdiknas Direktorat Pendas dan Menengah Direktoran TK dan SD, 2007). Meanwhile, Moeslichatoen (2004) stated that role playing is a playing activity that uses children's imagination with using language or acted to behave like a thing, some situation or people, animal that exist in real world. As such, children can learn to role play as other people while trying to understand the role being played. Depdiknas (2005) mentions that role playing activities gives certain experience to children through act and play in order to build assertiveness since early childhood

\section{CONCLUSIONS}

Investing assertive ability since early childhood includes behaviour that make children value other people and themselves. Consequently, they will have strong confidence of themselves. Assertive ability includes ability to express opinion, saying no, and value other people and themselves strongly. Bullying might resulting to children involved in violence which will create negative impact to them. Growing assertive can be done through habituation, role modelling activity, and role playing activity.

\section{ACKNOWLEDGEMENTS}

Acknowledgement of gratitude is sent to Graduate School of Universitas Pendidikan Indonesia who have facilitated training of this journal article including all the cost and also giving chance to improving the writing ability.

\section{REFERENCES}

Alberti, R., \& Emmons, R. (2002). Your perfect right: panduan praktis hidup lebih ekspresif dan jujur pada diri sendiri. Jakarta: Elex Media Komputindo.

Annual Bullying Survey. (2016). UK Bullying Statistics 2015 - Key Findings. Diakses dari website: http://www.ditchthelabel.org/annualbullying-survey-2016/

Benyamin, S. (2004). Seni mendidik anak. Jakarta: MM. Corp.

Black, S.A., \& Jackson, E. (2007). Using bullying incident density to evaluate the olweus bullying prevention programme. School psychology international, 2 (28) 125-143.

Bowers, W.J. (1964). Student Dishonesty and Its Control in College, Colombia University Bound. New York: McMillan.

Coloroso, B. (2007). Stop bullying (memutus rantai kekerasan anak dari prasekolah hingga smu). Jakarta: PT. Ikrar Mandiri Abadi.

Chesney-Lind., \& Meda, P.L. (2004). The female offender, girls, woman and crime. USA: Sage Pubs., Inc.

Depdiknas. (2005). Peraturan pemerintah republic Indonesia no. 19 th 2005 tentang standar nasional pendidikan. Jakarta: Dep Dik Nas. 
Depdiknas Direktorat Pendas dan menengah Direktorat TK dan SD. (2007). Pedoman pembelajaran bidang pengembangan pembiasaan di tk. Jakarta: Depdiknas Direktorat Pendas dan Menengah Direktorat TK dan SD.

Elliot, M. (2005). Wise guides bullying. New York: Hodder Children's Books.

Echols, J., \& Hassan, S. (1995). Kamus inggris indonesia. Jakarta: PT. Gramedia

Fadlillah, M., \& Mualifatu, L.K. (2013). Pendidikan karakter anak usia dini: konsep dan aplikasinya dalam paud. Jogjakarta: ArRuzz Media.

French, A. (1998). Keterampilan berkomunikasi antar pribadi. Indonesia: Kentindo Soho.

Komisi Perlindungan Anak Indonesia (KPAI). Diakses dari website: http://www.kpai.go.id/.

Mayang. (2014). Strategi pembelajar dan jenis kegiatan pengembangan yang di gunakan di TK?. Diakses dari Website:

https://mayangs027.wordpress.com/2014/04/21/strat egi-pembelajar-dan-jenis-kegiatanpengembangan-yang-di-gunakan-di-tk/

Moeslichatoen R. (2004). Metode pengajaran di taman kanak-kanak. Jakarta: PT Asdi Mahasatya

Muhammad, A. (2003). Karir maju dengan sikap assertive. Diakses dari Website: http://www.suaramerdeka.com/cybernews/wani ta/karir/karir_wanita ol.html

Murphy, A.G. (2009). Character education: Dealing with bullying. New York: Chelsea House Publishers

Olweus, D. (1993). Bullying at school: What we know and what we can do. Cornwall: Blackwell Publishing.

Palmer., \& Froehner. (2002). Penuntun menumbuhken harga diri bagi remaja. Jakarta: Gramedia.

Pratanti. (2007). Perilaku assertive dan perilaku agresif. Diakses dari website: http://www.indonesiannursing.com

Rathus, S. A., \& Nevid, J. S. (1983). Adjustment and growth: the challenges of life (2nd ed). New York: CBS College Publising.

Riauskina, I.I., Djuwita, R., \& Soesetio, S.R. (2005). Gencet gencetan di mata siswa/siswi kelas 1 sma: naskah kognitif tentang arti skenario, dan dampak gencet-gencetan. Jurnal Psikologi Sosial. 12. (01) 1-13.

Rigby, K. (2002). New perspectives on bullying. Jesica Kingsley Publisher: London.

Rini, J. (2001). Asertivitas. Diakses dari website: http://www. E-Psikologi.com.

Sunardi. (2010). Latihan Assertive. Makalah PLB FIB UPI. Diakses dari website:
http://file.upi.edu/Direktori/FIP/JUR._PEND._ LUAR_BIASA/196002011987031-

SUNARDI/karya_tlsmateri_ajar_pdf/LATIHAN_ASSERTIVE.pdf

Tattum, D. (1993). Understanding and managing bullying. Oxford: Heinemann School Managenment.

Tribun Lampung. (2016). Kasus bullying di lampung anak tk rebut bekal temannya lalu diinjak injak. Diakses dari website:

http://lampung.tribunnews.com/2016/01/24/kas us-bullying-di-lampung-anak-tk-rebut-bekaltemannya-lalu-diinjak-injak).

Willis, L., \& Daisley, J. (1995). The assertive trainer: a practical handbook assertiveness of trainers and running assertiveness course. USA: Mc Graw Hil.

Quiroz, HC., et al. (2006). Bullying in schools; fighting the bully batle. Retrieved from: http://www,schoolsafety.us/pubfiles/bullyingch alktalk.pdf. 